\title{
Improving Social Skills through Physical Education in Elementary 4th Year
}

\author{
Pedro Gil Madrona ${ }^{1, *}$, Amaury Samalot-Rivera ${ }^{2}$, Eva Cristina Gutiérrez Marín ${ }^{1}$, Jesús Rodenas-Jiménez ${ }^{3}$, \\ $\mathbf{M}^{\mathrm{a}}$ Llanos Rodenas-Jiménez ${ }^{4}$ \\ ${ }^{1}$ Facultad de Educación de Albacete. Universidad de Castilla La Mancha, Spain \\ ${ }^{2}$ State University of New York at Brockport Department of Kinesiology, Sport Studies, and Physical Education, EE.UU \\ ${ }^{3}$ Subdelegate of Students of School of Education. Universidad de Castilla La Mancha, Spain \\ ${ }^{4}$ English as a Foreign language teacher from. Consejería de Educación de Comunidad Madrid, Spain \\ *Corresponding author: Pedro.Gil@uclm.es
}

Received November 20, 2014; Revised December 15, 2014; Accepted December 25, 2014

\begin{abstract}
The purpose of this research is to check to what extent the application of a particular social skills program through the content block of games in physical education for students from four primary course these skills improved after implementation for a month (10 classes -sessions). The sample consisted of 24 students (12 boys and 12 girls) aged between 9 and 10 years in a center of the province of Albacete in Spain. It is a quasi-experimental prepost with no control group. As assessment tools students passed the Social Skills Questionnaire Ambezar group, consisting of 20 items to which we must respond with "almost always", "sometimes" and "almost never". After implementing the program are found to have increased social skills implemented. The boys spend an average of 1.68 in social skill at program startup to a 1.73 at the end of it, and students from 1.54 at baseline to 1.57 at the end.
\end{abstract}

Keywords: social skills, learning, games, physical education, elementary education

Cite This Article: Pedro Gil Madrona, Amaury Samalot-Rivera, Eva Cristina Gutiérrez Marín, Jesús Rodenas-Jiménez, and $\mathrm{M}^{\mathrm{a}}$ Llanos Rodenas-Jiménez, "Improving Social Skills through Physical Education in Elementary 4th Year.” American Journal of Sports Science and Medicine, vol. 2, no. 6A (2014): 5-8. doi: 10.12691/ajssm-2-6A-2.

\section{Introduction}

For over a decade we define social skills and behaviors that allow the child to interact with peers and environment in a socially acceptable manner [1]. These skills can be learned, and can range from the simplest to the most complex, including: Wave, smile, make favors, ask favors, make friends, express feelings, express opinions, defend their rights, start-keep-end conversations, some of these skills are very important to a child's success in the classroom and school [2].

Therefore there is no doubt of the importance of developing these skills in children as part of their overall training as people, including favoring a better social integration. Since as noted accelerated the changes in today's knowledge society, characterized by the impact of globalization, sometimes generating social imbalances, implied that diversity training needs and a these needs is the domain of people in social skills, justifying the desirability of undertaking such social skills in educational processes chords to the new social reality [3].

Some of these skills are very important to a child's success in the classroom and classroom skills such as cooperation, self-control and assertiveness. Of these, one of the most important is cooperation and self-control.

The Science of Physical Activity and Sport (CCAFD) are a set of disciplines, from different branches of knowledge, for the study of facts, processes or phenomena associated the practice of physical activity and sport in which emotions and social behaviors that occur in the practice of physical activity are included in their study [4]. Certainly, Physical Education can not only help children develop psychomotor skills, but can provide psychological benefits through the development of personal and social responsibility, and correct social behavior. However, the social growth of students is not an automatic result of participation in physical activity [5].

Different studies [6] identified certain social behaviors that influence school performance and children's learning. This includes listening and following directions, adequately participate in groups, staying vigilant in the work and the organization of work materials. These behaviors are known as "social skills related to learning" and are directly related to the success and adjustment of school-age students.

Certainly the planned instruction social development through sport and Physical Education has become a key player. In the model of instruction [7] the teaching of personal and social responsibility focuses on teaching students to be personally and socially responsible. The model has been used to build a sense of responsibility for personal development, well-being and learning, as well as to others inside and outside the gym. The model helps students develop social skills that can improve their academic performance. Indeed, social skills, physical 
education, contents and behaviors that can be learned and strengthened work. Some authors [8] also propose a model in which the learning of social skills in physical education where teachers can integrate directed activities within social systems students proposed through fair play in physical education. Much of the literature on the acquisition of social skills in the field of physical education has shown that the desired PE behaviors are within the broad concept called "Fair Game" [9,10,11].

As you rightly point, [12] in the communication process established by the teacher and the students can be differentiated tasks such as dynamic group, motivate, and organize the play area all very well managing the dynamics between the group and the social relations among them.

Another authors project the positive and direct behavior between the PE teacher and student behavior through fair play, although students continue to maintain verbal aggression relationship [13].

Social skills can help children to interact, to be accepted and imitate appropriate behaviors [14]. Thus Physical Education provides the opportunity for social acceptance among students as they participate in games and group activities drive, increase your chance of success in community $[15,16]$. Indeed, physical education is often a subject where the interests of the students are more related to socialize to learn content.

\section{Methods}

\subsection{Objectives}

The objective of this research is, on the one hand, to check to what extent the implementation of a didactic unit of social skills through the content block of games in Physical Education for students from the fourth year of Primary Education improves after implementing these skills during one month (10-session classes). And, on the other hand, getting students to improve their social relationships through the proposed activities in the teaching unit (which frees from inhibition, to communicate with others, to wait their turn when speaking or performing tasks, to know how to ask for help, etc.).

\subsection{Design and Context}

The participants in the study were a group of students from the 4th grade of Primary Education, with a total of 24 (12 boys and 12 girls) students from nine / ten years of a school in Albacete (Spain). This is a descriptive pre-post quasi-experimental design with no control group.

The characteristics of the group are fairly homogeneous, but it is worth mentioning three students, two of them have learning disabilities, one of which is repetitive and is easily distracted and another child with attention deficit that although he is affectionate and likes to please, is impulsive, distracted and is constantly aware of what is happening in class, but what it is important for him; and the third child who has not developed basic social skills.

\subsection{Program and Procedure}

The carried out procedure is to design a didactic unit to improve social skills through games. After designing the objectives, contents and evaluation sessions, it would be implemented for one month (10 classes) and it should be checked the effect produced.

The implementation program for the development of improved social skills in elementary school children has been followed through the content block based on games and with reference to the designed by Humberto Ulises Espino, Counselor of CAPEP Detection and Prevention Program [17] ("Ambezar Project." Psychology Care Center for Preschool and Primary).

Contents of social skills incorporated into the Physical Education Teaching Unit games. Rewarding oneself (to foster cooperation and applaud oneself for the help he has given and the achievement of the game). Ask for help (saying "I need help", seek help from your friends when you are in trouble or need support). Asking for a favor (planning what to say, ask, thank, if anyone acts unjustly, let him know). Ask a question (What to ask ?; Whom to ask ?; When to ask ?, make it easy to maintain a conversation, question-answer, ask when you do not understand something), Following instructions (listening, thinking, asking if necessary, when someone interrupts you when talking, tell him to stop and wait until you finish your turn. Trying when it is difficult, stop and think ( "it's hard but I'll try", try, react to situations with ease to unforeseen events), request attention (decide if you need, walk to the person waiting to say "sorry" or "excuse me", apologize when they know that they were wrong), interpret others (look at the face, looking at the body, manifest my opinions ). Joining a group (approaches the group, observe them, question, when someone beats them, or their team in a game or competition, congratulate when finished). Wait for your turn (it's hard to wait, but I can, to choose, to find the time to be quiet or entertaining, listen to the person speaking without interrupting until he finishes).

The proposed intervention has used a variety of techniques such as case studies, debates, cooperative research and small group discussions and brainstorming, resolving moral problems method, discovering values method, instilling the values and clarifying values methodology, critical understanding and role-playing.

\subsection{Tools}

To measure the social skills, a questionnaire called the Ambezar Social Skills Group [17] was used, each of the children in the pre and post, consisting of 20 items to which they must respond with a number, in which 3 means "almost always ", 2" sometimes "and 1" hardly ever ". The "Ambezar Project" pretends to help teachers in general and professionals in orientation in particular, to familiarize with new concepts and terms and how to organize coherent responses to the rule and the actual situation of the centers. To correct, the number of points assigned to each question are added and multiplied by 5 and the result is divided by 2 to find the percentage of socially skilled behavior in situations that the questionnaire collects.

\section{Results}

In Table 1, Table 2, Table 3 and Table 4 it can be seen that after the implementation of the improvement program of Social Skills in Physical Education through content 
blocks in games, has been a quantitative advance in boys and girls in the fourth grade in the targeted social skills. Boys go from an average of 1.68 to 1.73 in social skills, and girls from 1.54 to 1.57 .

Table 1. - Average scores for the Pre and Post questionnaire

\begin{tabular}{ccc}
\hline $\begin{array}{c}\text { AVERAGE SCORES } \\
\text { FROM THE QUESTIONNAIRE }\end{array}$ & PRE & POST \\
\hline BOYS & 1,68 & 1,72 \\
GIRLS & 1.55 & 1,57 \\
\hline
\end{tabular}

Table 2. Percentage of socially skilled behavior of the students in the pre and post

\begin{tabular}{llll}
\hline $\begin{array}{l}\text { NUMBER } \\
\text { OF }\end{array}$ & $\begin{array}{l}\text { INITIAL } \\
\text { PERCENTAGE }\end{array}$ & $\begin{array}{l}\text { FINAL } \\
\text { PERCENTAGE }\end{array}$ & DIFFERENCE \\
GIRLS & OF SOCIAL & $\begin{array}{l}\text { OF SOCIAL } \\
\text { SKILLS }\end{array}$ & SKILLS \\
\hline 1 & $65 \%$ & $67,5 \%$ & $2,5 \%$ \\
3 & $60 \%$ & $65 \%$ & $5 \%$ \\
5 & $65 \%$ & $77,5 \%$ & $12{ }^{\prime} 5 \%$ \\
6 & $62,5 \%$ & $70 \%$ & $7 ’ 5 \%$ \\
9 & $77,5 \%$ & $82,5 \%$ & $5 \%$ \\
10 & $75 \%$ & $80 \%$ & $5 \%$ \\
12 & $65 \%$ & $75 \%$ & $10 \%$ \\
13 & $75 \%$ & $85 \%$ & $10 \%$ \\
16 & $62,5 \%$ & $60,5 \%$ & $-2 \%$ \\
17 & $77,5 \%$ & $87,5 \%$ & $10 \%$ \\
19 & $57,5 \%$ & $67,5 \%$ & $10 \%$ \\
\hline
\end{tabular}

Table 2 shows a great increase in the development of social skills in girls, highlighting girl number 5, who has the widest range of the result from the initial rate to the final percentage (65\% -77.5\%).It was observed, from items such as "I often react to situations with ease or unforeseen events" and "I manifest my opinions to my parents, although I anticipate that there may be slips" it is selected "sometimes" or "almost always". It has to be pointed out that student number 21 has not progressed in that student development and number 16 has gone backwards.

Table 3. Pupils' Socially adept behaviour in at the beginning and at the end percentage

\begin{tabular}{|c|c|c|c|}
\hline $\begin{array}{l}\text { N. of } \\
\text { ppPupils }\end{array}$ & $\begin{array}{l}\text { Initial social } \\
\text { skskills percentage }\end{array}$ & $\begin{array}{l}\text { fFinal social skill } \\
\text { pePercentage }\end{array}$ & Difference \\
\hline 2 & $62,5 \%$ & $70 \%$ & $7 ’ 5 \%$ \\
\hline 4 & $67,4 \%$ & $75 \%$ & $7^{\prime} 6$ \\
\hline 7 & $60 \%$ & $75 \%$ & $15 \%$ \\
\hline 8 & $35 \%$ & $47,5 \%$ & $12 ’ 5$ \\
\hline 11 & $72,5 \%$ & $75 \%$ & 2'5\% \\
\hline 14 & $75,2 \%$ & $72,5 \%$ & $-2{ }^{\prime} 5 \%$ \\
\hline 15 & $65 \%$ & $67,5 \%$ & $2 ’ 5 \%$ \\
\hline 18 & $60 \%$ & $62,5 \%$ & $2 ’ 5 \%$ \\
\hline 20 & $57,5 \%$ & $60 \%$ & $2 ’ 5 \%$ \\
\hline 22 & $52,5 \%$ & $62,5 \%$ & $10 \%$ \\
\hline 23 & $62,5 \%$ & $65 \%$ & $2 ’ 5 \%$ \\
\hline 24 & $70 \%$ & $72,5 \%$ & $2 ’ 5 \%$ \\
\hline
\end{tabular}

Table 4. Comparison between the questionnaire's items at the beginning and at the end

\begin{tabular}{|c|c|c|c|c|c|c|}
\hline \multicolumn{4}{|c|}{ INITIAL EVALUATION (PRE) } & \multicolumn{3}{|c|}{ FINAL EVALUATION (POST) } \\
\hline ITEM & Average & S.E & $\begin{array}{l}\text { 95\% CONFI. } \\
\text { INTERVAL }\end{array}$ & Average & S.E & $\begin{array}{l}\text { 95\% CONFI. } \\
\text { INTERVAL }\end{array}$ \\
\hline $\begin{array}{l}\text { 1. When I or my team lose in a competition I congratulate } \\
\text { the winner. }\end{array}$ & 1.375 & .1175304 & $\begin{array}{c}1.13187- \\
1.61813\end{array}$ & 1.458333 & .1200719 & $\begin{array}{c}1.209946- \\
1.706721\end{array}$ \\
\hline $\begin{array}{l}\text { 2. I usually ask for help to my friends when I'm in a } \\
\text { trouble. }\end{array}$ & 1.541667 & .1038946 & $\begin{array}{c}1.326744- \\
1.756589\end{array}$ & 1.583333 & .1191252 & $\begin{array}{c}1.336904- \\
1.829763\end{array}$ \\
\hline $\begin{array}{l}\text { 3. If someone makes me a practical joke I express my } \\
\text { discomfort. }\end{array}$ & 2.083333 & .1334691 & $\begin{array}{l}1.807231- \\
2.359435\end{array}$ & 2.041667 & .1408973 & $\begin{array}{l}1.750198- \\
2.333135\end{array}$ \\
\hline $\begin{array}{l}\text { 4. When someone express an opinion and I do not agree } \\
\text { with it, I express my point of view based on reasons. }\end{array}$ & 1.875 & .1512329 & $\begin{array}{l}1.562151- \\
2.187849\end{array}$ & 1.583333 & .1464145 & $\begin{array}{l}1.280452- \\
1.886215\end{array}$ \\
\hline $\begin{array}{l}\text { 5. To start and keeping a conversation with an unknown } \\
\text { easy for me. }\end{array}$ & 1.75 & 1379193 & $\begin{array}{l}1.464692- \\
2.035308\end{array}$ & 1.75 & .1379193 & $\begin{array}{l}1.464692- \\
2.035308\end{array}$ \\
\hline $\begin{array}{l}\text { 6. If my parents or a teacher say something that I consider } \\
\text { that is wrong, I try to counter them }\end{array}$ & 2.291667 & .1532163 & $\begin{array}{l}1.974715- \\
2.608619\end{array}$ & 2.416667 & .1334691 & $\begin{array}{c}2.140565- \\
2.692769\end{array}$ \\
\hline $\begin{array}{l}\text { 7. When I do not understand something in class, I ask to } \\
\text { the teacher. }\end{array}$ & 1.458333 & .1200719 & $\begin{array}{l}1.209946- \\
1.706721\end{array}$ & 1.5 & .1203859 & $\begin{array}{l}1.250963- \\
1.749037\end{array}$ \\
\hline 8. I usually apologize when I recognize that I was wrong. & 1.375 & .1175304 & $\begin{array}{l}1.13187- \\
1.61813\end{array}$ & 1.416667 & .102799 & $\begin{array}{l}1.204011- \\
1.629323\end{array}$ \\
\hline $\begin{array}{l}\text { 9. When in a group conversation someone talks in a bad } \\
\text { way about a friend I defend them against the rest of the } \\
\text { group. }\end{array}$ & 1.5 & .1345955 & $\begin{array}{l}1.221568- \\
1.778432\end{array}$ & 1.291667 & .094776 & $\begin{array}{l}1.095608- \\
1.487726\end{array}$ \\
\hline $\begin{array}{l}\text { 10. I listen to the person who is talking without } \\
\text { interrupting until he finishes. }\end{array}$ & 1.541667 & .1200719 & $\begin{array}{l}1.293279- \\
1.790054\end{array}$ & 1.625 & .1175304 & $\begin{array}{l}1.38187- \\
1.86813\end{array}$ \\
\hline $\begin{array}{l}\text { 11. When a friend does something bad for me, I express } \\
\text { my disagreement without hiding what I feel. }\end{array}$ & 1.875 & .125 & $\begin{array}{l}1.616418- \\
2.133582\end{array}$ & 1.875 & .1387378 & $\begin{array}{l}1.587999- \\
2.162001\end{array}$ \\
\hline $\begin{array}{l}\text { 12. I show my opinions to my parents although thinking } \\
\text { in possible disagreements. }\end{array}$ & 1.541667 & .1343148 & $\begin{array}{l}1.263815- \\
1.819518\end{array}$ & 1.833333 & .1554175 & $\begin{array}{l}1.511828- \\
2.154839\end{array}$ \\
\hline $\begin{array}{l}\text { 13. I participate in debates when I think that I can give } \\
\text { something }\end{array}$ & 1.416667 & .1191252 & $\begin{array}{l}1.170237- \\
1.663096\end{array}$ & 1.333333 & .0982946 & $\begin{array}{l}1.129995- \\
1.536671\end{array}$ \\
\hline 14. If I see a person acting unfairly, I will tell him/her. & 1.583333 & .1191252 & $\begin{array}{c}1.336904- \\
1.829763\end{array}$ & 1.416667 & .1191252 & $\begin{array}{l}1.170237- \\
1.663096\end{array}$ \\
\hline $\begin{array}{l}\text { 15. When someone interrupts me when I am talking, I ask } \\
\text { for let me finishing and respecting each turn. }\end{array}$ & 1.625 & .1451199 & $\begin{array}{l}1.324797- \\
1.925203\end{array}$ & 1.625 & .1175304 & $\begin{array}{l}1.38187- \\
1.86813\end{array}$ \\
\hline $\begin{array}{l}\text { 16. I deal with my parents the time for coming back home } \\
\text { when I go out. }\end{array}$ & 2.083333 & .1464145 & $\begin{array}{l}1.780452- \\
2.386215\end{array}$ & 2.041667 & .1532163 & $\begin{array}{l}1.724715- \\
2.358619\end{array}$ \\
\hline $\begin{array}{l}\text { 17. When someone apologizes and I feel that these } \\
\text { apologies are honest. I accept them. }\end{array}$ & 1.541667 & .1343148 & $\begin{array}{c}1.263815- \\
1.819518\end{array}$ & 1.25 & .0902894 & $\begin{array}{c}1.063222- \\
1.436778\end{array}$ \\
\hline $\begin{array}{l}\text { 18. If someone notices me about I am annoying in some } \\
\text { way, I stop doing this. }\end{array}$ & 1.583333 & .1334691 & $\begin{array}{c}1.307231- \\
1.859435\end{array}$ & 1.458333 & .1200719 & $\begin{array}{l}1.209946- \\
1.706721\end{array}$ \\
\hline $\begin{array}{l}\text { 19. When someone makes me a funny joke, I accept it and } \\
\text { I laugh with the rest of people. }\end{array}$ & 1.5 & .1345955 & $\begin{array}{l}1.221568- \\
1.778432\end{array}$ & 1.166667 & .0982946 & $\begin{array}{l}.9633287- \\
1.370005\end{array}$ \\
\hline $\begin{array}{l}20 \text {. I tend to react to situations or unforeseen events with } \\
\text { ease. }\end{array}$ & 1.375 & .1175304 & $\begin{array}{l}1.13187- \\
1.61813\end{array}$ & 1.583333 & .102799 & $\begin{array}{l}1.370677- \\
1.795989\end{array}$ \\
\hline
\end{tabular}


Boys (Table 3) have has a bigger progress than girls. Seeing the results, boys, have a better socially adept behaviour than girls. It's important to remark boy n. 8, who shows an incredible progress relating to the skills I wanted to develop in them. Initially, he was a boy with problems in relationships, no having much relation with his classmates, he found difficult to express his feelings and show his complains. After the implementation of the improvement tasks, he shows an excellent progress, and bit by bit, he was able to show his feelings, he cooperates in his classmates' games, he asks for help when needed, and the communication with the rest of school community is better. He looks happier about coming to the school and specially to Physical Education lessons.

In general terms, both boys and girls have improved relating to the use of their social skills. Questionnaire items with the bigger progress (these ones in which pupils cross "mostly") have been: Item 1 . When I or my team lose in a competition I congratulate the winner. Item 6: If my parents or a teacher say something that I consider that is wrong, I try to counter them. Item 8: I usually apologize when I recognize that I was wrong.. Item 10: I listen to the person who is talking without interrupting until he finishes. Item 12: I show my opinions to my parents although thinking in possible disagreements. And Item 20: I tend to react to situations or unforeseen events with ease.

\section{Discussion and Conclusions}

After looking the results, we conclude that the development of social skills, by the use of games in Physical Education in Primary Education is absolutely necessary. The results have been positive; pupils now learn and improve their social skills by playing and having a fun time. Therefore $[18,19]$ teachers have an essential role in the development of these skills. It means, that social skills will be developed when they are introduce in the curricula and used during the lessons. So, as we have show in this research, social skills can be learnt, pupils, at the school must learn an appropriate behaviour in order to avoid future problems as in class as in their daily life [20].

After analysing the results, we can observe that boys at the beginning have a higher level of social skills than girls, and also that there are some pupils (both boys and girls) who have a higher level than others.

It's true that some pupils had got these skills in other contexts out of the school. But others did not show these skills owing to the fact of not having learnt them before.

\section{References}

[1] Sheridan, S.M. The tough kid social skills book. Longmon, CO: Sopris West. 2000.
[2] Samalot-Rivera, A. y Porreta, D.L. "Perceptions and practices of adapted physical educators on the teaching of social skills". Adapted Physical Activity Quarterly, 26, 172-186. 2009.

[3] Granero Gallegos, A. y Baena Extremera, A. "Juegos y deportes de aventura en la formación permanente del profesorado”, Revista Internacional de Medicina y Ciencias de la Actividad Física y el Deporte vol. 11 (43), 531-547. 2011. 8 de Febrero de 2013. Disponible: Http://cdeporte.rediris.es/revista/revista43/artjuegos224.htm.

[4] Devís Devís, J., Valenciano Valcárcel, J., Villamón, M. y PérezSamaniego, V. "Disciplinas y temas de estudio en las ciencias de la actividad física y el deporte", Revista Internacional de Medicina y Ciencias de la Actividad Física y el Deporte vol. 10 (37), 150-166. 2010. 8 de Febrero de 2013. Disponible: http://cdeporte.rediris.es/revista/revista37/artdisciplinas147.htm.

[5] Wallhead, T. y O'Sullivan, M. "Sport Education: Physical Education for the new millennium?”. Physical Education \& Sport Pedagogy, vol.10 (2), 181-210. 2005.

[6] McClelland, M. M. y Morrison, F.J. "The emergence of learningrelated social skills in preschool children”. Early Childhood Research Quarterly, 18 (2), 206-224. 2003.

[7] Hellison, D. Teaching responsibility through physical activity $\left(2^{\mathrm{a}}\right.$ ed.). Champaign, IL: Human Kinetics. 2003.

[8] Vidoni, C. y Ward, P. "Effects of Fair Play Instruction on student social skills during a middle school Sport Education unit". Physical Education. \& Sport Pedagogy, 14 (3), 285-310. 2009.

[9] Siedentop, D., Hastie, P. A. y Van der Mars, H. Complete guide to sport education Champaing, IL: Human Kinetics. 2004.

[10] Siedentop, D., y Tannehill, D. Developing teaching skills in physical education. Mountain View, C. A.: Mayfield Publishing Co.2000.

[11] Vidoni, C. y Ward, P. "Effects of a dependent group-oriented contingency on middle school physical education students' fair play behaviors". Journal of Behavioral Education, 15, 81-92.2006

[12] Valera Tomás, S.; Ureña Ortín, N.; Ruiz Lara, E. y Alarcón López, F. "La enseñanza de los deportes colectivos en Educación Física en la E.S.O”. Revista Internacional de Medicina y Ciencias de la Actividad Física y el Deporte vol. 10 (40), 502-520. 2010. 9 de Febrero de 2013. Disponible:

Http://cdeporte.rediris.es/revista/revista40/artdeportes135.htm.

[13] Mary, H. Alexandra, B. y Kimon, S. "Physical education teacher's verbal aggression and student's fair play behaviors". Physical Educator, 64, 94-101. 2007.

[14] Espino, U. H. "Programa detención y prevención". 2011. 9 de Febrero de 2013. Disponible: http://capep9.jimdo.com/informaci\%C3\%B3n-para-padres-defamilia/el-juego-y-las-habilidades-sociales/.

[15] Lane, K.L., Givner, C.C. y Pierson, M. R. "Teacher expectations of student bechavior: Social skills necessary for success in elementary school classrooms". The Journal of Special Education, 38, 104-111. 2004.

[16] Meier, C. R., DiPerna, J.C. y Oster, M. M. "Importance of social skills in elementary grades”. Education y Treatment of Children, 29, 409-419. 2006.

[17] Aranda Rufián, C. "Recursos para la atención a la diversidad." 2011. 7 de Febrero de 2013. Disponible: http://www.juntadeandalucia.es/averroes/ambezar/.

[18] Block, M. E. A teacher's guide to including children with disebilities in general physical education ( $\left.3^{\text {rd }} \mathrm{ed}\right)$. Baltimore, MD: Brookes. 2007.

[19] Gil-Madrona, P. y Gutiérrez Marín, E. C. Madrid López, P.D. "Incremento de las habilidades sociales a través de la expresión corporal”. Cuadernos de Psicología del Deporte, vol. 12, Suplemento 2, 83-88. 2012.

[20] Llanos Baldivieso, C. C. "Efectos de un programa de enseñanza en habilidades sociales". Tesis doctoral. Editorial de la universidad de Granada. 2006. 